\title{
Place, Silence, and local Memory IN TODO É SILENCIO BY MANUEL RIVAS
}

\author{
NeIL D. Anderson \\ Texas Tech University
}

AвstRaCt: This article addresses issues of local memory in Manuel Rivas's novel Todo ésilencio (2010) and takes as its starting point Pierre Nora's twin notions of lieu de mémoire and milieu de mémoire. By focusing on a specific site portrayed in the novel — the escola de indianos, a building that once housed a progressive school— we analyze the ways in which the author deploys the building not merely as a setting, but also as aestheticization of the interstices between history, memory, and forgetting.

Keywords: Manuel Rivas, Todo é silencio, memory, lieux de mémoire, forgetting, milieux de mémoire, escola de indianos.

Lugar, Silencio e memoria local en Todo é siLencio de Manuel Rivas

Resumo: Este artigo examina cuestións de memoria local na novela Todo é silencio (2010) de Manuel Rivas, tomando coma punto de partida as nocións parellas de lieu de mémoire e milieu de mémoire propostas por Pierre Nora. Centrámonos nun espazo concreto representado na novela - a escola de indianos, un edificio que nun momento histórico determinado acolleu un modelo escolar progresista - para analizar os diferentes xeitos en que o autor fai uso dese espazo non só coma un escenario senón tamén coma unha estética das físgoas entre a historia, a memoria e o esquecemento.

Palabras chave: Manuel Rivas, Todo é silencio, memoria, lieux de mémoire, esquecemento, milieux de mémoire, escola de indianos.

Pierre Nora has written that «Memory takes root in the concrete, in spaces, gestures, images, objects» (1989: 9) and draws the distinction between milieux de mémoire, cultures or environments that are propitious to living memory, and lieux de mémoire, sites that encase and curate memory and are «fundamentally remains, the ultimate embodiments of a memorial consciousness that has barely survived in a historical age that calls out for memory because it has abandoned it» (Nora 1989: 12). This article explores the spaces between lieux de mémoire and milieux de mémoire in Manuel Rivas's Todo é silencio (20I0), a novel which, as María Xesús Lama López (2014) has pointed out, 
combines bildungsroman and crime novel as it portrays the dynamics of power and corruption in a coastal Galician town beset by organized crime. My analysis focuses on spaces in which memory is not yet fully curated, codified into history, but where memory is not quite alive, either. ${ }^{1}$ These are spaces in which local memory and local knowledge are contested, where memory fails, where the past has been overwritten, effaced, perhaps, like a palimpsest, barely legible, recoverable only in part. They are spaces from which people avert their gaze in order not to see, not to remember. In moving toward an examination of these in-between spaces, we may do well to consider these spaces as sites of haunting, as spaces inhabited by a spectral presence and where the past has unfinished business. Acknowledging that these spaces exist requires that we accept what Avery Gordon describes as the theoretical importance of the fact that all people «remember and forget, are beset by contradiction, and recognize and misrecognize themselves and others» (1997: 4). For Gordon, the study of haunting is not a sign of superstition or psychosis, but rather an essential component of the study of social life. In the context of such inquiry, literary fiction allows access to «other kinds of sociological information» (1997: 25), it grants access to «the ensemble of cultural imaginings, affective experiences, animated objects, marginal voices, narrative densities, and eccentric traces of power's presence» (1997: 25).

My analysis focuses on a specific site portrayed in Rivas's novel, the escola de indianos, a building that once housed a progressive school conceived and funded by Galicians abroad. I argue that the school functions in the novel as an interstitial space between history, memory, and forgetting, a place that indexes the truncation of progressive culture in Galicia that began with the Spanish Civil War (1936-1939) and came to sponsor a culture of silence that persisted throughout the Franco dictatorship (1939-1975) and beyond. I argue, further,

Eugenia Romero (20I2) and William J. Nichols (2006) have both studied the work of Manuel Rivas through Nora's concept of lieux de mémoire. Romero analyzes textual elements of En salvaxe compaña (1994) such as the Pazo de Arán, the parish of Arán, the santa compaña, the parish cemetery — as well as the reader as an extra-textual site of memory — as lieux de mémoire that «create a space for criticism and review of Galicia’s history» (Romero 20I2: 48). Nichols, for his part, argues that Rivas's O lapis do carpinteiro (1998), in addition to offering up oral tradition as antidote to the silencing of voices marginalized by historiography, «propone ciertos objetos físicos como lieux de mémoire que rescatan y no reprimen el pasado al ofrecer un espacio donde la memoria puede residir» (Nichols 2006: 17I). 
that despite the fact that Brétema, the fictional coastal town in which the nov$\mathrm{el}$ is set, is no longer a milieu de mémoire, a place with a habit of remembering, the village still bears traces of local memory and knowledge, traces that are concentrated in the escola. ${ }^{2}$ Thus, Rivas's return to the escola at various points in the narration signifies a collective need to «giv[e] speech back to the ghost $[\mathrm{s}]$ » (Derrida 1994: 22I) of the past, a process which, owing to the tensions and failures inherent in the recovery of memory, renders the escola a site of what María do Cebreiro Rábade Villar (20ıı: I77), in her discussion of Rosalía de Castro’s poetics, has paradoxically called «restitución desposuída».

\section{A SCHOOL IN RUINS, or the Aesthetics of Collective Loss}

On one level, the ruins of the escola de indianos stand as a reminder of the efforts of Galician migrant communities who, by deploying the economic and ideological capital gained in the Americas, sought to influence what kind of place Galicia would become by establishing schools that would bring literacy, practical skills, and cosmopolitan values back to their home regions (Costa Rico 2008: 15). Even more specifically, the Unión Americana de Fillos de Brétema represents a type of asociacionismo that Xosé M. Núñez Seixas (I998: 83) identifies as microterritorial, in which emigrants from the same village or town would form organizations, often with the intent of planning and funding projects for the places they left behind. Núñez Seixas points out the importance of local identity for these emigrants, and cites the Galician doctor Ángel Anido who, writing in 1898 , recognized the pride of place held by the patria chica: «Reconocemos la conveniencia de declararnos hijos de la patria grande [...] pero el corazón nos vende; el primer impulso es para la patria pequeña. Y es que allí están la casa donde nacimos y la calle donde, siendo niños, hemos jugado con el desenfado propio de los pocos años» (qtd. in Núñez Seixas ig98: 83). Notwithstanding such nostalgic framings, the progressive nature of asso-

2 As Lama López points out, «a denominación da vila onde se sitúa a acción era inicialmente Brétema, pero despois da primeira edición mudou para Noitiá a causa dunha polémica por suposto plaxio coa escritora Marina Mayoral, que xa usara ese mesmo topónimo ficticio en varias obras» (Lama López 2014: 103). As I quote here from the first edition, I have chosen to refer to the town as Brétema.

Abriu, 4 (2015): 13-27

ISSN: 2014-8526, e-ISSN: 2014-8534. DOI: 10.1344/abriu2015.4.I 
ciationist projects - like that of the fillos de Brétema - demonstrates how love of place can play a part in the broader political project of what Rivas has called «facer o amor co futuro» (Rivas 2009: 24) and how local identity can be inscribed within a framework of social activism that operates across borders and at various geographic scales.

On another level, though, Rivas uses the escola de indianos to show how past dreams of the future haunt the present as failures and ruins. If Rábade Villar has noted Rosalía de Castro's use of «microtoponimia na construción de lugares que non adoita cantar dende a celebración, senón dende a perda» (20II: I77), Rivas's escola offers a microtoponomy of loss and oblivion. When as readers we first see the school from the point of view of the four teenagers exploring it, however, the school is decontextualized, almost prehistoric. The front wall of the schoolroom is described as «descolorida como pinturas rupestres» (Rivas 20I0: 28) and the furniture and collections that once filled the school are described as having burned «noutro tempo, nun período tamén arcaico, fóra do tempo, que os maiores chamaban Guerra» (2010: 28). For these characters, born in the I950s, the Civil War and the other events of the first half of the 20 th century may as well have taken place in Paleolithic times. Significantly, though, the school that Rivas depicts, while in ruins, still refuses to fall, it is «Unha desas ruínas que queren esboroarse e non o conseguen, e ás que as hedras que cobren os muros non as fenden, senón que as vendan» (Rivas 2010: 26), alluding perhaps to the latent viability of progressive social projects. Nature, in the form of climbing ivy, rather than destroying the building, seems to be holding it in trust for the future, and although it is in disrepair, the building's very design still speaks to the cosmopolitan values that brought it into being; its floor is a map of the world in relief that allowed each student to sit «nun recanto do mapamundi. E movíase ao longo dos anos, de tal xeito que cando rematase podía dicir que era un cidadán do mundo» (Rivas 20ı0: 26), a geographic movement which the young lovers Leda (Nove Lúas) and Fins re-enact:

—Onde estás, Fins?

- Na Antártida. E ti?

—Eu estou na Polinesia.

—Estás ben lonxe! (Rivas 2010: 59).

This enactment serves both to connect Leda and Fins to the students of the past, and as a preamble to the their microgeographic movement toward 
one another, thus connecting the cosmopolitan with the erotic: «Achegábanse. Encontráronse. Tócanse [...] Nove Lúas percorre cos dedos o mapa do rostro de Fins Malpica» (Rivas 2010: 60).

By connecting Fins and Leda to the students of the past, Rivas points to possibility of addressing the failure of historical memory experienced by his generation and by the previous one during the dictatorship. According to Rivas, in I950s Galicia «o que dominaba era un silencio mudo e un ambiente cultural desmemoriado, ruín e hostil» (Rivas 2009: I8). The notion of a silencio mudo is drawn from Rosalía de Castro’s poem «PPadrón...! ¡Padrón...!» published in Follas Novas ( 1880 ):

Aquelas risas sin fin, aquel brincar sin dolor, aquela louca alegría, ¿Por qué acabou?

Aqueles doces cantares, aquelas falas d'amor, aquelas noites serenas, ¿Por qué non son?

Aquel vibrar sonoroso das cordas da arpa i os sons da guitarra malencónica, ¿quen os levou?

Todo é silensio mudo, soidá, delor, ond' outro tempo a dicha sola reinou... (Castro [1880] I993: I88).

This silencio mudo runs throughout the novel and is often associated with the escola, as we will see. By taking up the poetics of the silencio mudo, Rivas replicates what Rábade Villar calls the productive «tensión entre o que se nomea e o que é radicalmente alleo á denominación» (20II: I77) that is so often present in Castro's oeuvre. In the poem, o silencio mudo supplants the sounds of laughter, love, and music associated with an earlier time, leaving the poetic voice behind as a trace, a witness to lost plenitude whose discourse is frac- 
tured by interrogatives, a poetic strategy that works to resist «calquera vía rápida de lexitimación dos suxeitos afectados pola desposesión» and thus offers «testemuño real do que supón ser un desposuído» (Rábade Villar 20II: I78). In the novel, when Leda, inside the ruins of the school, opens a book out of idle curiosity — «abriuno por abrir» (Rivas 20I0: 6I) — and discovers Castro's poem, she enters a space inhabited by a voice that hails her from the past. As Leda reads, the educational project of the Fillos de Brétema emerges, albeit fleetingly, from the school's ruined archive; like the town's collective memory, the book is shot through with erasures, «ten sucos de piollos» (Rivas 2010: 6r) that threaten the recovery of the text. Even so, Leda wants to pass the text along to Fins, and asks him to copy the poem on the school's ancient typewriter as she reads. When Fins protests that he does not have any paper, Leda knows that it does not matter; the important thing is the practice of memory, the passing along from one to another, dredging the neural canals through which memory flows, a process that Rivas, following the philosopher Edward Casey, calls «lembrar relembrando» (Rivas 2009: I0-II). ${ }^{3}$ Leda seems to intuitively trust that the text has something to say, even if she does not understand it; if the text reproduces the seseo of coastal Galicia — «todo é silensio» (Castro [1880] I993: I88)— Leda affirms, «Por algo será» (Rivas 2010: 6I). That sibilant is a socio-phonetic commentary, an echo of local linguistic practice that stands to remind Leda of where she is from, who her people are, and what their voices sound like. Ironically, then, while Castro's poem laments the reign

3 Edward Casey is an American philosopher who has written extensively on memory and forgetting. Rivas's formulation «lembrar relembrando» claims to be a rough translation of «remembering re-member», which he attributes to Casey (Rivas 2009: Io). It is possible that Rivas misquotes Casey here; he may have been referring to Casey's «remember remembering», which appears in the following context: «I come to rely on data banks and mass media to hold and transmit memories for me. Not only do I not do my own remembering, I have forgotten to remember. I no longer know how to remember effectively or even what I want to remember. In this state I am failing to remember remembering» (Casey [1987] 2000: 4; emphasis in original). Whatever the case, though, both Casey and Rivas are both interested in memory as a practice that is both iterative and intentional. In «lembrar relembrando», the second term modifies the first, yielding something like «to remember by remembering», a notion that resonates with Casey's hope that the modern subject might reassert its agency in matters of memory, and «take seriously once more the genuine weight of memory instead of mindlessly opting for the spurious lightness of forgetting» (Casey [1987] 2000: 4). 
of silence, the poem itself serves symbolically to counter the silence in which Brétema is submerged.

The escola de indianos, then, is a space haunted by literature, where the past speaks to Leda and Fins through Castro's poem. This is a narrative manifestation of Rivas's argument in his essay A boca da literatura (2009) that hegemonic silence may be countered by accessing the nearly mythical power of literature to redeem humanity in its darkest moments, to plant itself and grow in the darkest of crevices: «As verbas son sobreviventes que agroman malferidas, reticentes e resentidas polas fendas das ruínas» (Rivas 2009: 19). But far from being a utopian space dedicated to the recovery of memory and collective identity, the escola de indianos is a contested space where numerous discourses flow together and are superimposed. Leda, who, as we have just seen, is at first associated with remembering or rediscovering the knowledge hidden in the school, becomes, as the novel progresses, an advocate for forgetting; if Castro's poem speaks words that «agroman malferidas», Leda becomes an agent of their eradication. Leda's transformation parallels the bipartite temporal structure of the novel (which in some sense parallels the temporal structure of Castro's poem): the first third of the book bears the title «O silencio amigo» and corresponds to the main characters' teenage years — «aquel brincar sin dolor» (Castro [1880] I993: I88) — while the remainder of the narration, «O silencio mudo», takes place more than a decade later, a time of «soidá, dolor» (Castro [1880] I993: 188) in which Brétema is firmly gripped by the hegemony of silence.

When, early in the second part of the novel, Leda and Fins meet again in the school, the building has become, somewhat paradoxically, more of a ruin but also more full of light: «O buraco do teito agrandara e no mapa do chan reducíranse as zonas de penumbra» (Rivas 2010: 122). This imagery counters the notion that the past necessarily falls into obscurity; the relationship between walls held together by ivy and the roof that, with time, recedes into nothingness is exactly the kind of relationship «between what assembles and joins and what is gaping, detouring, and haunting» that Gordon believes literature can illuminate (1997: 27; emphasis in original). Indeed, Leda and Fins' different reactions to the space point to the plurality of experiences a given space can engender. Fins focuses on the light, observing that «Vese mellor. Tes as unllas pintadas de negro. Estás no Océano» (Rivas 2010: I22). Fins thus begins to reenact the game they played as teenagers, fixing Leda's coordinates on the map, a game that, along with the rest of his youth in Brétema, is etched 
in Fins's memory: «Lembreime de ti, de todo, máis do que podes imaxinar» (Rivas 2010: 122). Fins, then, is a practitioner of memory; he is now a detective by profession, and as such, his métier consists in bringing the past into the light, in doing what Derrida (I994: I22) called giving back speech to the ghosts of the past. But Leda's riposte is a movement back into darkness and forgetting: Leda «retrocede até apoiarse na mesa dun pupitre, de novo na penumbra» and tells Fins «Pois eu non. Eu aprendín a esquecer. Cada día e cada hora. Son unha experta en esquecementos» (Rivas 2010: 122).

The school is thus a site of clandestine encounters where discourses of memory and forgetting flow together, compete, and cancel each other out. Returning to the first section of the novel, when the group of teenagers first explore the dilapidated school, we see that Mariscal and his collaborators have a discourse of their own through which they seek to define the site. The teenagers find the building filled with cases of contraband whiskey; the site has become one of Mariscal's many depots. The school's identity as a symbol of social progress has been overwritten as the school is literally occupied by Mariscal's smuggling operation. Rumbo forbids the teenagers to go there, and Mariscal warns them away from the school: «Ese lugar está... endemoñado. Sempre o estivo!» (Rivas: 20I0: 54). On a first reading, these warnings and prohibitions seem mundane, a case of adults trying to keep kids out of trouble, to curb their «louca alegría» (Castro [1880] I993: I88). On another level, though, the word endemonado points to the school as a site of haunting, a place where «time is out of joint», where the ghost is none other than the projects of the past that seek restitution, to be recognized and thus saved from oblivion (Derrida i994: 22-23). The school, then, is a site in which the structure of time seems to be altered, folded in on itself in a way that threatens to undo the illusion that the present is free, unmoored from any past or future time. Gordon, following Terry Eagleton, theorizes the ghost as that which «registers the actual 'degraded present' in which we are inextricably and historically entangled and the longing for the arrival of a future» (Gordon 1997: 207; emphasis in original); in steering the teenagers away from the school, the adults seek to exorcise the town's geography of this demon that registers the «degraded present», to erase it or push it back into obscurity. For Mariscal, controlling the building that once housed the school means keeping the site from becoming a space where memory can take root (Nora 1989: 9), thus promoting the collective amnesia that keeps him firmly in control of Brétema. Amnesia is Mariscal's ally, a fact he attempts to obfuscate with platitudes such as «o silencio do que sabe é 
unha substracción para a humanidade» (Rivas 2010: 9I). If, as John P. Thompson points out, a specter is «unha memoria fragmentada e marxinada do saber colectivo en procura dun lieu de mémoire para ser inscrita na Historia» (2009: 69), Mariscal's true project is to keep the spirit of progress that haunts the school in a state of desarraigo, rootless and fragmentary and thus invisible to History. In an inversion of the notion of the foraxido, a criminal who flees town to escape justice, Mariscal is a criminal who manipulates the town so that justice, the ghost's desideratum, is kept at bay.

Part of this manipulation, as I have mentioned, involves Mariscal's occupation of the school, an occupation that goes beyond the physical. When Mariscal discovers the teenagers exploring the escola, his words change the structure of the youths' memory of being in the school, his discourse on secrecy and silence threatens to overwrite their first-hand sensory experience of the school. Mariscal proclaims, «Os habent, et non loquentur. Teñen boca e non falan. Se aprendedes isto, tendes media vida gañada» (Rivas 20I0: 31; emphasis in original); his is a discourse of erasure that seeks to relegate into nonexistence what the teenagers may have seen or experienced inside the school: «Ben, tropa... aquí non pasou nada. Non oístes nada. Non vistes nada» (Rivas 20I0: 3I). Through his negation of the teenagers' own experience, Mariscal attempts to interfere with the very cognitive machinery of memory making. This will to authority on Mariscal's part produces here and throughout the novel a tension over what we might call the «question of Brétema», the question of who decides what kind of place Brétema will be, whether a plurality of views and experiences will flow together to form a town that each subject can regard as her own, or whether, by contrast, the town will be populated by people who «Teñen ollos e non ven... Teñen oído e non oen» (Rivas 20I0: 31), morphologically human but stripped of all subjectivity and therefore of the ability to make of their town a truly vital space in which memory and affect animate the material world.

\section{Chelín: Putting Memory to Sleep}

For as much as it portrays a town in which freedoms are circumscribed, Rivas's novel is not a portrait of a post-human dystopia, but rather a case study of the banal yet socially paralyzing effects of hegemony. If, as I have suggest$\mathrm{ed}$, the escola is a site that serves as a metaphor for social and ideological fault 
lines that run through Brétema, the character of Chelín, who in the second part of the novel takes up residence in the school, offers insight into how those fractures are lived and experienced at the level of the individual.

Chelín, a heroin addict and synecdoche of the xeración perdida that fell victim to Galicia's drug tide (sometimes called the marea blanca, especially in reference to cocaine) of the I980s, is privileged as one of the only first-person narrators in the novel; his voice issues from within the escola de indianos, which he describes as «o meu sitio. O meu zulo» (Rivas 2010: II7). Through this repetition of the possessive, Chelín expresses the extent to which he identifies with the school and views it as a comfortable, homely home. But given that the site is associated with Mariscal's discourse of anesthesia and silence, Chelín's comfort there reveals the extent to which he has assimilated Mariscal's rhetoric and come to imagine the school in a manner wholly divorced from the values it originally represented. So convinced is he of the legitimacy of his tenure that when Fins enters the school, Chelín feels licensed to ridicule him as an outsider, noting that his footfalls break the silence, rousing the bats that hang from the ceiling: «Levan meses aí, pendurados, remoendo a sombra, e xusto agora espertan. Oír si que oen, digo eu, e ese, o Malpica, xa perdeu o xeito de pisar. Quen ía pensar que acabaría de feo. Vai batendo en todos os accidentes xeográficos. Comigo están en paz. Eu son de aquí» (Rivas 2010: II7; emphasis mine). In contrast to the notion of places as emergent, dynamic phenomena whose ontological status is best described not in terms of being but rather of becoming, here Chelín's criticism of Fins reflects a closed, static, and proprietary view of the school and, by extension, of Brétema. For Chelín, Fins represents an alien presence, something out of place that disturbs the peace Chelín has created for himself through acquiescence to the local status quo. Far from seeing this capitulation as a defeat, Chelín celebrates himself as an authentic fillo de Brétema, proclaiming «eu son de aquí». Moreoever, Chelín takes Fins' failure to wend his way gracefully around the geographic features that rise from the school's floor, as proof that Fins, in spite of being a Brétema native, has been denatured by his time away, rendered foreign. In this way, he invokes a discourse of belonging that is «locals only», exclusionary in nature, an assertion that others do not belong.

While I argue earlier that the map built into the escola is a representation of the open, cosmopolitan project of the indianos, Chelín's alternative conception of the map provides a stark illustration of the ways in which the meaning of places is often contested, always subject to revision, and how the relative 
material stability and continuity of physical sites contrasts with the mutability of the ideologies with which those sites are freighted. Chelín's essentialist attitude of it was ever thus is a willful obfuscation of this mutability, and plays into the collective anesthesia - literally, the lack of sensation: «teñen ollos e non ven» (Rivas 2010: $3 \mathrm{I}$ )— promoted by Mariscal. Part of Fins' project in returning to Brétema as a detective is to counter this social tendency through professional hyperesthesia: surveying secret spaces, listening, smelling, and, in collaboration with fellow detective Mara Doval, elaborating a new map of Brétema that attempts to make sense of the town's place in global criminal flows:

Mapamundi con anotacións fixadas con alfinetes: Paraíso fiscal, Off-shore, Porto base, Barco nutriz, Transvasamento, Desembarco, Alixo... Tamén trazos de rutas e viaxes, sinaladas en diferentes cores. A liña negra indica tabaco, a amarela, videotapes, e unha terceira, en vermello, cocaína. Unha verde, desprazamento de persoas (Rivas 2010: 194).

Both the police and Mariscal's organization use mapping as a tool in the struggle to determine Brétema's course, thus pointing to cartography as not only a representation or calque of that which is, but as means of manipulating and controlling what will be. ${ }^{4}$ Ironically, though, Chelín is insensitive to ways in which those around him are motivated by a desire to shape the future, and his purblindness causes him to see Fins' return to Brétema and to the school as merely a sentimental trip down memory lane: «Este aínda andará a remoer os tempos do Johnnie Walker [...] Misión nostalxia, Malpica!» (Rivas 20ı0: I2I). Just as Chelín has little sense of the future, he also has little respect for the past; his residency in the school has been marked by forgetting and erasure, and his worldview is predicated on ratifying the present: «Leda traballa no Ultramar. Ten un fillo con Brinco. E Brinco, Brinco é o máximo» (Rivas 20I0: I2I). Chelín characterizes even his own youth as part of the distant past: «Pasou un século, un milenio» (Rivas 20ı0: I2I); in line with this devaluation

${ }_{4}$ Bruno Bosteels points out that English translations of Gilles Deleuze and Félix Guattari often obscure the difference between «tracing» (calque) and «trace» (trace): «a calque by definition depends upon a pre-existing original or model» (Bosteels 1996: 378). I have used calque here to emphasize the way in which mapping is often thought of as a straightforward representation of space, in spite of the interpretive process that any mapping entails. 
of the past, he has sold much of the school's contents, including an insect collection, for drugs, thus converting the dreams of the fillos de Brétema into heroin. Chelín relates the trade this way: «Eu xa lle dixen ao ghicho. "Tráioche o Xénese enteiro, isto vale un potosí." E vai el e deume unha boliña de cabalo. "Pois velaí tes a esfera terrestre, para que a metas pola vea." Para iso deron as especies, para un xute» (Rivas 2010: II8). Chelín is aware of the irony and senses that the transaction symbolizes a loss of something significant; perhaps the loss of the «esfera terrestre» is the loss of the fillos de Brétema's cosmopolitan dream, or perhaps the conversion of the dream into a nightmare in which Brétema is linked to the world not through the flow of ideas but through the flow of drugs. But whatever misgivings Chelín may have count for little. Chelín refuses to offer the ghosts of the school what Derrida has called «a hospitable memory» (1994: 175) like the hermit crab that he so admires, Chelín has put the school to use for his own purposes, relegating the original inhabitants to oblivion. Chelín, like Leda and Mariscal, is an advocate of forgetting; in an inversion of his former teacher's saying «Somos o que lembramos», Chelín holds that «Somos o que esquecemos» (Rivas 2010: I19). In his words, «Cando esquezo algo, remexo coa lingua na falta da moa. Métense aí os esquecementos. Teño aí un zulo que é un pozo sen fondo» (Rivas 20Io: II9). Chelín’s body has become a bottomless well where all that is forgotten is lost forever; although it is stored in the body and becomes part of us, it can never be accessed. Chelín, by accepting this inaccessibility, symbolically breaks with his own family's past and with his father the poceiro who was famous for being able to locate the water that flowed hidden deep underground.

This embracing of desmemoria leaves Chelín in the eternal present, where all that is left for the school's history books to do is to hold his heroin spoon: «A culleriña ben presa, enxertada entre os dous volumes de La civilización. Don Pelegrín Casabó y Pagés. O útiles que me son os memoriais. O agradecido que estou á civilización. Colocado á altura da súa obra, ter as mans ceibas para darlle candea ao cabalo na auga» (Rivas 20ı0: II9). Chelín has become the antithesis of the bricoleur or gleaner who Jo Labanyi, following Walter Benjamin and David Frisby, characterizes as one who «rummages around in the debris or litter left by the past, and reassembles the fragments in a new 'constellation' that permits the articulation of that which has been left unvoiced» (Labanyi 2000: 69). Although Chelín may resemble a bricoleur in that he repurposes the school's contents, his is an un-bricolage that serves to further disarticulate the past and contribute to the sense of collective anesthesia and amnesia; with every in- 
jection, Chelín feels less and remembers less, paying tribute to Morpheus by putting memory to sleep and overdubbing it with silence.

\section{CONCLUSION: THE SCHOOL BURNS}

Returning to the characters of Fins and Leda, we have already seen that Rivas links their movement in and out of memory and forgetting to their movement in and out of light and shadow within the escola. When Leda bids Fins to return to the escola in one of the final scenes of the novel, Rivas once again deploys light and shadow in an aestheticization of their relationship and of the contested status of the site. ${ }^{5}$ Fins and Leda now occupy the liminal space between lightness and dark, the two move «No bordo claroscuro» (Rivas 2010: 270), signifying the «question of Brétema» that hangs in the balance: Will the town move definitively toward light and memory, or will it retreat once again into the shadows of forgetting? Will it continue to deny its ghosts, or will it offer them a dwelling place? These interrogatives bring us back to the poetics of «restitución desposuída» where «o sentido de pertenza e o sentido de desherdanza» (Rábade Villar 20ıı: I78) comingle: Fins and Leda occupy a caesura, a moment in which there are no heroes or villains, only fillos de Brétema, inheritors of Brétema's past with all its contradictions and gaps, its history both progressive and caciquil, its tenderness and its violence.

This moment of suspension comes to an end, and in the novel's last scenes the school burns. But even as this concrete reminder of one aspect of the town's history is destroyed, the «question of Brétema» - lits relationship to its past and to its future - still persists, for the fire signifies both loss and renewal, a turning toward the future. By giving the escola a prominent place in the novel and by ultimately allowing it to be destroyed, Rivas binds his narration in the «nó fechado da 'restitución desposuída'» (Rábade Villar 20Iı: I78), remembering the fillos de Brétema while at once drawing attention to the caducity of their project. Moreover, by refusing to make of the school a lieu de mémoire, Rivas

5 This return to the school recalls the last section of Castro's poem «iPadrón...! ¡Padrón...!», in which the poetic voice returns to a beloved place in search of the people she once knew there, only to find it deserted, or rather, inhabited by shadows, ghosts: «Mirei pola pechadura | ique silensio!... ique pavor!... | vin nomais sombras errantes | qu' iban e viñan sin son | cal voan os lixos leves | nun raio do craro sol» (Castro [I880] I993: I9I).

Abriu, 4 (2015): 13-27

ISSN: 2014-8526, e-ISSN: 2014-8534. DOI: 10.1344/abriu2015.4.I 
reminds us that local memory depends less on the crystallization of history in sites planned and curated as memory delivery systems, and more on the subject who remembers as a part of the process of imagining and building the future. Walter Benjamin, for his part, points to the relationship between the subject of memory, the process of discovery, and the site where the past enters his consciousness: «a función das lembranzas verdadeiras non é testemuñar o pasado, senón describir precisamente o lugar no que o buscador tomou posesión del» (qtd. in Rábade Villar 2oıı: 9). Rivas's novel, to the degree that it rejects lieux de mémoire in favor of milieux de mémoire, also moves away from testimony and ratifies an ethics of relation instead of one of mere representation. Although in the end nothing may remain of the escola de indianos, Leda's final words in the novel, uttered in response to Mariscal's question regarding the contents of the suitcase she carries out of the burning building, speak not to what is lost, but to what remains: «Cousas miñas. Lembranzas» (Rivas 2010: 274). With these words, Leda takes possession of the memories that have been sepulchered in the school and allows a crack to form in her identity as «unha experta en esquecementos» (Rivas 2010: I22) suggesting that she, like Brétema itself, occupies a haunted space between history and forgetting, memory and silence.

\section{WORKS CITED}

Bosteels, Bruno (1996). «A Misreading of Maps: The Politics of Cartography in Marxism and Poststructuralism». Stephen Barker (ed.). Signs of Change: Premodern > Modern > Postmodern. Albany: SUNY, Iog-138.

CASEy, Edward ([1987] 2000). Remembering: A Phenomenological Study. Bloomington: Indiana University Press.

Castro, Rosalía de ([1880] 1993). Follas novas. Eds. Henrique Monteagudo and Dolores Vilavedra. Vigo: Galaxia.

Costa Rico, Antón (2008). «Emigrantes, escuelas y regeneración social: Los emigrantes gallegos a América y el impulso a la educación (1879-1936)». Revista Brasileira de História da Educação, I6, 13-46.

Derrida, Jacques (1994). Specters of Marx. New York: Routledge.

Gordon, Avery (1997). Ghostly Matters: Haunting and the Sociological Imagination. Minneapolis: University of Minnesota Press.

LabanyI, Jo (2000). «History and Hauntology; or, What Does One Do with the Ghosts of the Past? Reflections on Spanish Film and Fiction of the Post-Franco Period». 
Joan Ramon Resina (ed.). Disremembering the Dictatorship: The Politics of Memory in the Spanish Transition to Democracy. Amsterdam: Rodopi, 65-82.

Lama LóPez, María Xesús (2014). «Novela negra ou hibridación do xénero? A cara máis íntima do mal en Todo é silencio de Manuel Rivas». Abriu, 3, 97-ıo9.

Nichols, William J. (2006). «La narración oral, la escritura y los 'lieux de mémoire’ en El lápiz del carpintero de Manuel Rivas». Ulrich Winter (ed.). Lugares de memoria de la guerra civil y el franquismo. Madrid: Iberoamericana, 155-176.

Nora, Pierre (1989). «Between Memory and History: Les Lieux de Mémoire». Representations, 26 Special Issue: Memory and Counter-Memory, 7-24.

Núñez Seixas, Xosé M. (1998). Emigrantes, caciques e indianos: O influxo sociopolítico da emigración transoceánica en Galicia (1900-1930). Vigo: Xerais.

Rábade Villar, María do Cebreiro (20II). Fogar impronunciable: Poesía e pantasma. Vigo: Galaxia.

Rivas, Manuel (2009). A boca da literatura: Memoria, ecoloxía, lingua. A Coruña: Real Academia Galega.

Rivas, Manuel (2010). Todo é silencio. Vigo: Xerais.

Romero, Eugenia (2012). Contemporary Galician Culture in a Global Context: Movable Identities. Lanham: Lexington Books.

Thompson, John P. (2009). As novelas da memoria: Trauma e representación da historia na Galiza contemporánea. Vigo: Galaxia. 